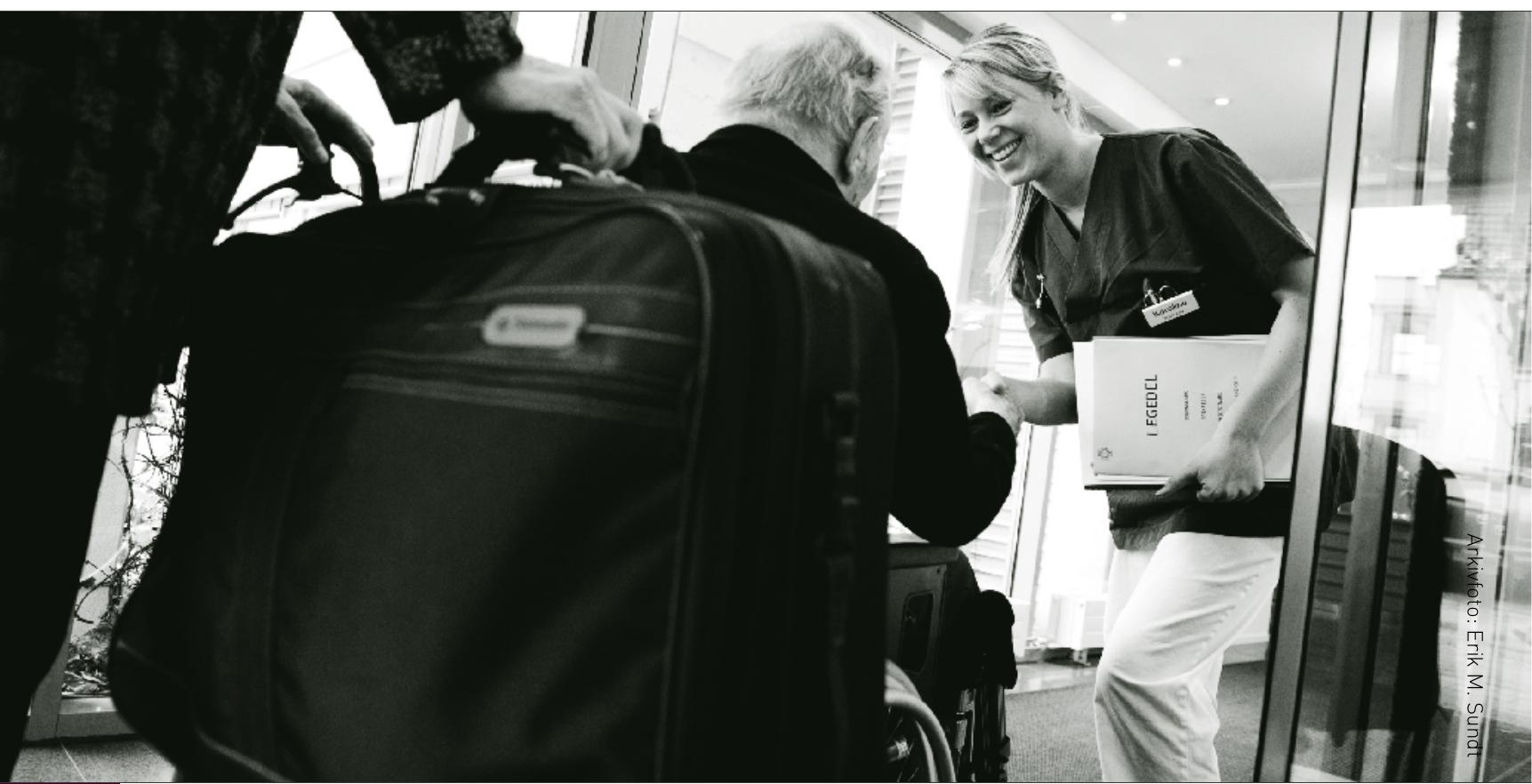

Bakgrunn: Innføringen av Samhandlingsreformen har satt utfordringene knyttet til det å organisere helsetjenestene til en økende andel svært gamle på den politiske dagsorden. En av de viktigste utfordringene knytter seg til hvilket nivå tjenestene skal ytes på, og hvordan de ulike nivåene i omsorgskjeden kan spille sammen for å gi et best mulig tilbud.

Hensikt: Hensikten med denne artikkelen er å gi en empirisk testing av følgende hypotese: kommuner med utstrakt bruk av korttidsplasser har somatiske pasienter 80 år og eldre lavere liggetid i sykehus.

Metode: I analysen benyttes multippel sekvensiell regresjonsanalyse basert på data fra 408 kommuner.

Resultater: Analysen viser at somatiske pasienter på 80 år og eldre har lavere liggetid i sykehus i kommuner med utstrakt bruk av korttidsplasser. Artikkelens hypotese får dermed støtte. Selv om korttidsplassene forklarer relativt lite av variasjonen i antall liggedøgn, har andelen korttidsplasser en betydning for liggetiden på somatiske sykehus for de eldste som er statistisk signifikant, også når vi kontrollerer for en rekke andre relevante variabler

Konklusjon: Resultatene i denne artikkelen er basert på data fra 2010 og 2011, det vil si før Samhandlingsreformen ble satt i virksomhet. Det virker imidlertid rimelig å anta at betydningen av korttidsplasser vil tilta under denne reformen.

\section{Organised for cooperation?}

Background: The introduction of the Cooperation reform in Norway has highlighted the challenges of organizing health care for an increasing proportion of very elderly citizens. One of the most important challenges concerns the level at which the services should be provided, and how the various levels in the care chain can interact in order to create the best services possible.

Objective: The aim of this article is to empirically test the following hypothesis: Patients over 80 years of age have shorter stays in somatic hospitals if they live in municipalities with a high proportion of shortterm places in municipal care institutions, than if they live in a municipality with few such places.

Method: The analysis is based on multiple sequential regressions on data from 408 Norwegian municipalities.

Results: The analysis confirms that patients over 80 years of age have shorter stays in somatic hospitals if they live in municipalities with a high proportion of shortterm nursing home beds. This is in line supports our hypothesis. The availability of short-term nursing home beds explains relatively little of the total variation in the dependent variable, but the effect is statistically significant, even when controlled for a number of other relevant variables.

Conclusion: The results in this analysis are based on data from 2010-2011, that is, before the Coordination reform was implemented. However it seems reasonable to assume that the impact of shorttermbeds in nursing homes will increase after the implementation of the reform.

Keywords: nursing homes, patients ready for discharge, elderly. 


\section{»Organisert for samhandling?}

Forfattere: Åsmund Hermansen

og Anne Skevik Grødem

\section{NøKKELORD}

- Sykehjem

- Kommune

- Spesialisthelsetjenesten

- Samhandling

- Eldre

\section{INNLEDNING}

Antallet eldre over 80 år i befolkningen øker. I 2011 utgjorde personer over 80 år 4,5 prosent av befolkningen i Norge, og Statistisk sentralbyrå beregner at denne andelen kommer til å øke til 11,7 prosent i 2100 (1). Selv om mange eldre har god helse, øker antallet helseproblemer med alderen, og sykeligheten blant de aller eldste er høyere enn i befolkningen for øvrig. Tall for 2007 viser at pasienter over 80 år forbrukte 16,4 prosent av alle liggedøgn ved norske sykehus (2). En høyere andel eldre i befolkningen vil dermed innebære større etterspørsel etter helsetjenester. Eldre har også oftere enn andre komplekse helseproblemer, med flere diagnoser samtidig. Dette innebærer at helsetjenestene til denne gruppa kan stille andre krav til helsepersonell enn det arbeid med yngre pasienter gjør.

Hvordan «eldrebølgen» best kan håndteres har vært et politisk tema i flere år, og utfordringene knyttet til det å organisere helsetjenestene til en økende andel svært gamle kommer bare til å bli mer sentrale i politikken i årene som kommer. En av de viktig- ste utfordringene knytter seg til hvilket nivå tjenestene skal ytes på, og hvordan de ulike nivåene i omsorgskjeden kan spille sammen for å gi et best mulig tilbud. Denne artikkelen tar opp et aspekt ved denne problematikken, nemlig forholdet mellom liggedøgn på sykehus og antallet korttidsplasser i kommunale sykehjem. Kan det å bygge opp korttidstilbud på sykehjem bidra til færre liggedøgn i sykehus for de aller eldste pasientene? Det å få ned antallet liggedøgn på sykehus, blir ofte oppfattet som et mål i seg selv. Siden den første stortingsmeldingen som lanserte en målbeskrivelse for helsetjenestene i Norge, (3), har «laveste effektive omsorgsnivå» (LEON) vært et sentralt prinsipp. Kommunene har over tid fătt tilført stadig mer ansvar for helse- og omsorgstjenester (4), og denne utviklingen har kulminert i Samhandlingsreformen, som ble innført fra 1. januar 2012. En av de sentrale målsettingene med reformen er å dempe veksten i sykehussektoren ved gradvis å rendyrke spesialisthelsetjenestene ved sykehusene. Samtidig skal kommunehelsetjenesten settes i stand til å påta seg større helsefaglige og pleiemessige oppgaver (5).

Et sentralt mål er at sykehuspasienter skal utskrives raskere, og overføres til kommunale pleieog omsorgstjenester. Kommunene pålegges et medfinansieringsansvar. Dette innebærer at kommunene må bidra til å dekke kostnadene som påløper sykehu- sene den tiden utskrivningsklare pasienter blir liggende på somatiske sykehus på grunn av manglende kapasitet i kommunale tjenester. Dette gir kommunene et sterkt økonomisk incentiv til å innrette pleie- og omsorgstjenestene slik at de er i stand til å motta utskrivningsklare pasienter for videre behandling. Det kommunale medfinansieringsansvaret omfatter i første omgang pasienter som skrives ut fra medisinske avdelinger, hvor en majoritet av pasientene er eldre. Samhandlingsreformen gjør det derfor enda viktigere enn før for kommunene å ha et godt apparat for utskrivningsklare (eldre) pasienter. Korttidsplasser på sykehjem kan være et viktig virkemiddel i så måte. I denne artikkelen søker vi å utvikle en forståelse av hvor viktige korttidsplassene er. Vi

\section{Hva tilfører artikkelen?}

Artikkelen underbygger at flere kommunale kortidsplasser gir god pasientstrøm og lavere liggetid i somatiske sykehus, og derfor er en måte og møte Samhandlingsreformens utfordringer på.

\section{Mer om forfatterne:}

Åsmund Hermansen har mastergrad i statsvitenskap fra Universitetet i Oslo og jobber som stipendiat ved Fafo, Institutt for arbeidslivs- og velferdsforskning. Anne Skevik Grødem har doktorgrad i sosiologi fra Universitetet i Oslo og jobber som forsker I ved Fafo, Institutt for arbeidslivsog velferdsforskning. Kontakt: asmund.hermansenafafo.no. 
bruker data fra før reformen ble innført, men vi antar at mekanismene vil være de samme også etter at reformen kom på plass.

\section{BAKGRUNN}

«Før hadde sykehusene ferdigbehandlete pasienter', nå sier man <utskrivingsklare». Det er ikke en tilfeldig endring i terminologi. 〈Utskrivingsklar〉 forutsetter at pasienten får behandling et annet sted. Kommunen får behandlingsansvar, ikke bare pleieansvar.» munene og sykehusene. Departementet argumenterer for at $\varnothing \mathrm{kt}$ og riktigere bruk av korttidsplassene er en forutsetning for å kunne ta imot utskrivningsklare pasienter fra sykehusene som ikke kan bo hjemme rett etter et sykehusopphold, og dessuten for å kunne opprettholde innsatsen fra pårørende gjennom bedre avlastning, og for å sikre at hjemmetjenesten fungerer optimalt. Det finnes imidlertid lite forskning om hvilken funksjon korttidsplassene fyller i de kommunale pleie- og

\section{Et sentralt mål er at sykehuspasienter skal utskrives raskere.}

Sitatet ovenfor er hentet fra en toppleder i en av de store kommunene i Norge, som ble intervjuet sommeren 2012 om utfordringene $\mathrm{i}$ den kommunale helseog omsorgssektoren (4). Den kommunale lederen setter ord på en utvikling som har pågått gjennom flere år; en reduksjon i antallet liggedager på sykehus har vært en trend helt siden tidlig på 1990-tallet (5). Som påpekt er det et ideal at pasientene skal få omsorg på det laveste effektive omsorgsnivå, hvilket som regel vil være en kommunal institusjon framfor sykehus for utskrivningsklare pasienter. Samtidig har det vært et ideal i eldreomsorgen gjennom flere år å bygge ut hjemmetjenestene, slik at pasientene i minst mulig grad har behov for sykehjem (6). Balansen mellom sykehus, sykehjem og hjemmetjenester for de aller eldste er tilbakevendende temaer i diskusjonen om eldreomsorgen.

I omsorgsmeldingen (7), Mestring, muligheter og mening framheves betydningen av et tilstrekkelig tilbud av korttidsplasser i sykehjem for å sikre god flyt og samhandling mellom kom- omsorgstjenestene (8). De studiene som finnes er ofte avgrensete. Flere av dem bruker data kun fra en kommune - og de konsentrerer seg om andre tema enn forholdet mellom utbygging av korttidsplasser og antall liggedøgn på sykehus. Like fullt er en gjennomgående konklusjon at korttidsplasser bidrar til en mer effektiv ressursbruk, og at de bidrar til å bedre flyten mellom ulike nivåer i helse- og omsorgstjenestene innenfor kommunene. Korttidsplassene fyller et rom mellom hjemmetjenestene og langtidsplassene i institusjon. Her yter man hjemmetjenestene til eldre med begrenset bistandsbehov, mens $70-80$ prosent av beboerne på institusjonene er demente $\mathrm{og}$ til dels svært krevende (9). I spennet mellom den hjemmebaserte og den institusjonsbaserte omsorgen kan det oppstå et vakuum der tradisjonelle hjemmetjenester er utilstrekkelige, samtidig som kapasiteten på institusjonssiden mangler. Korttidsplasser bidrar til å fylle dette vakuumet $(9,10)$.

En annen side av dette er at korttidsplasser kan bidra til å bedre gjennomstrømningen på sykehjemmene, og dermed til mer effektiv bruk av tilbudet (10-12). Studier viser at kommuner med en høy andel korttidsplasser i institusjon har bedre tilgjengelighet til institusjonsplasser enn kommuner med lav andel korttidsplasser. Dette til tross for at den samlede dekningsgraden av institusjonsplasser var lavere $\mathrm{i}$ disse kommunene $(12,13)$. Kommunene med lavest samlet dekningsgrad, men med høyt innslag av korttidsplasser, hadde dessuten høyest utskrivningsrate fra sykehjem per 100 innbyggere på 80 år og eldre. Dermed hadde de den beste tilgjengeligheten på institusjonsplasser. Otterstad og Tønseth (12) konkluderer: "Jo høyere utskrivingsrate fra korttidsplasser, desto større er den samlede pasientsirkulasjonen". Deres konklusjon er at det er bruken av korttidssengene som forklarer en betydelig del av tilgangen til sykehjemsplasser, og mer enn hva dekningsgraden gjør. Otterstad og Tønseth understreker imidlertid behovet for en god samhandling mellom det institusjonsbaserte og den hjemmebaserte omsorgen, slik at eldre som har muligheten til å bo i egen bolig skal kunne gjøre det med støtte fra tjenestene. Effektiv bruk av korttidsplasser forutsetter samhandling og helhetlige løsninger når det gjelder bolig og tjenester. Gitt dette, vil god kapasitet av korttidsplasser kunne gi gunstige kostnadsmessige effekter. Kommunene vil kunne redusere omfanget av institusjonsplasser og erstatte disse med flere hjemmebaserte tjenester (14).

Studiene sitert så langt viser altså at korttidsplasser kan bidra til å «olje hjulene» i kommunale pleie- og omsorgstjenester, men de berører i liten grad forholdet til spesialisthelsetjenesten og 
helseforetakene. Den eneste norske artikkelen som har diskutert dette spesielt, brukte statistikk fra Østfold over utskrivningsklare pasienter (15). Analysen viste at "overliggerne» $\mathrm{i}$ hovedsak var pasienter som trengte utskrivning til institusjon. Studien konkluderer med at kommunenes dekning av korttidsplasser er meget viktig for å få til et effektivt samarbeid mellom pleie- og omsorgssektoren i kommunene og sykehusdriften når det gjelder geriatriske pasienter. For kommuner med et manglende tilbud av korttidsplasser fungerer sykehusene som en avlastning, noe Otterstad (15) omtaler som «sykehjemsfunksjonen i sykehus».

Ingen av de foreliggende bidragene har foretatt representative statistiske analyser for samtlige norske kommuner. Det er derfor ikke mulig å gi et generelt bilde av korttidsplassenes betydning for pasientstrømmene og dermed liggetiden i somatiske sykehus. Samhandlingsreformen har endret arbeidsdelingen mellom statlige helseforetak og kommunale tjenester. Det er likevel for tidlig å si noe om hvilke effekter reformen har hatt på kommunale pleie- og omsorgstjenester, og kommunenes tendens til å utnytte den mulige «sykehjemsfunksjonen i sykehusene». Men ved hjelp av foreliggende data, er det mulig å undersøke betydningen av korttidsplasser for liggetiden i somatiske sykehus umiddelbart før Samhandlingsreformen ble innført med full styrke. Siktemålet med denne artikkelen er å belyse betydningen av korttidsplasser i kommunale institusjoner, for antallet liggedøgn i somatiske sykehus, for pasienter 80 år og eldre. Dette vil gi grunnlag for å si noe om hvordan de kommunale pleie- og omsorgstjenestene vil utvikle seg i møte med Samhandlingsreformen og kommunalt medfinansieringsansvar for utskrivningsklare pasienter. Konkret er formålet med denne artikkelen å gi en empirisk testing av følgende hypotese: I kommuner med utstrakt bruk av korttidsplasser har somatiske pasienter 80 år og eldre lavere liggetid i sykehus. «Utstrakt bruk» defineres her som «over gjennomsnittlig bruk» av korttidsplasser. I 2010 var i gjennomsnitt 20,47 prosent av alle døgn i kommunale institusjoner på korttidsplass, men det var stor variasjon rundt gjennomsnittet.

\section{METODE}

For å teste artikkelens hypotese benyttes multippel sekvensiell regresjonsanalyse. Ved hjelp av en slik tilnærming er det mulig å studere hvilken betydning «andel liggedøgn tidsbegrenset opphold» har for «antall liggedøgn i somatiske sykehus per pasient 80 år og eldre», kontrollert for andre forklaringsvariabler. Videre er det mulig å studere endringer i betydningen av «andel liggedøgn tidsbegrenset opphold» når andre forklaringsvariabler introduseres. Norske kommuner utgjør analyseenhetene i den multippel sekvensielle regresjonsanalysen.

\section{DATAGRUNNLAG}

Analysen som gjennomføres er basert på registerdata fra NPR (Norsk Pasientregister) og KOSTRA (KOmmune-STat-RApportering) for årene 2009, $2010 \mathrm{og}$ 2011. Videre er det innhentet opplysninger fra Statistisk sentralbyrås befolkningsstatistikk. Registerdataene fra NPR er offentlig tilgjengelig gjennom Helsedirektoratet og er publisert i sammenheng med forberedelsene til innføringen av Samhandlingsreformen. Disse dataene innehol- der blant annet opplysninger om antall pasienter 80 år og eldre $i$ somatiske sykehus og liggetid for denne pasientgruppen fordelt på kommunenivå. KOSTRA er et nasjonalt informasjonssystem som gir styringsinformasjon om kommunal virksomhet, og dataene er offentlig tilgjengelig gjennom Statistisk sentralbyrå. Disse dataene gir informasjon om kommunale tjenester og bruk av ressurser på ulike tjenesteområder blant norske kommuner. I utgangspunktet inneholder NPR og KOSTRA informasjon om alle Norges 430 kommuner, men det er ikke mulig å inkludere alle kommuner i den kommende analysen på grunn av manglende verdier på sentrale variabler. I alt inkluderes 408 kommuner i den fulle analysemodellen.

\section{ANALYSEMODELL}

Den avhengige variabelen i analysen er «antall liggedøgn i somatiske sykehus per pasient 80 år og eldre (x1)» i 2011. «Antall liggedøgn i somatiske sykehus per pasient 80 år og eldre» er operasjonalisert ved å dele «antall liggedøgn totalt for somatiske pasienter 80 år og eldre» på "antall somatiske pasienter 80 år og eldre» for hver enkelt kommune i 2011.

"Andel liggedøgn tidsbegrenset opphold (x2)» er, som følger av artikkelens hypotese, en sentral uavhengig variabel. Variabelen er operasjonalisert ved å dele «antall liggedøgn tidsbegrenset opphold» på «antall liggedøgn i kommunale institusjoner totalt» for hver enkelt kommune i 2010. En fordel ved å undersøke bruken av korttidsplasser på denne måten er at man får et direkte mål på hvordan den enkelte kommune disponerer den totale institusjonskapasiteten. Man får også målt andelen av den kapasiteten 
som disponeres til korttidsplasser. En svakhet er imidlertid at kommuner med svært få institusjonsplasser totalt, men hvor disse institusjonsplassene $\mathrm{i}$ all hovedsak benyttes til korttidsopphold, vil oppnå en lik verdi på variabelen som kommuner med langt flere institusjonsplasser. Slik sett vil to kommuner, hvor det absolutte volumet $\mathrm{i}$ antall liggedøgn tidsbegrenset opphold er svært forskjellig, kunne oppnå samme verdi på variabelen når det gjelder «andel liggedøgn tidsbegrenset innbyggere 80 år og eldre i 2010 (x4)» i analysen. Denne variabelen er operasjonalisert ved å dele «antall mottakere av hjemmetjenester 80 år og eldre» på «antall innbyggere 80 år og eldre».

Brukergrunnlaget legger viktige rammer for utformingen av tjenestetilbudet innen pleie- og omsorgssektoren i den enkelte kommune. For å kontrollere for ulikheter i brukergrunnlaget, inkluderes «andel mottakere med omfattende bistandsbehov (x5)». Denne variabelen er operasjonali-

\section{Korttidsplasser kan bidra til å «olje hjulene» i kommunale pleie- og omsorgstjenester.}

opphold» av alle liggedøgn i kommunale institusjoner totalt. For å kontrollere for betydningen av at volumet $\mathrm{i}$ antall institusjonsplasser vil variere mellom kommuner, inkluderes «dekningsgraden av institusjonsplasser for innbyggere 80 år og eldre (x3)» i 2010 som kontrollvariabel i analysen. Denne variabelen er operasjonalisert ved å dele «antall beboer på institusjon 80 år og eldre» på «antall innbyggere 80 år og eldre».

En satsing på korttidsplasser, for etterbehandling og rehabilitering etter sykehusopphold, vil ofte kreve at kommunene yter hjemmebaserte tjenester når korttidsoppholdet er avsluttet og pasientene flytter hjem. Slik det framkom i gjennomgangen av tidligere forskning om bruken av korttidsplasser, er samspillet med hjemmetjenestene en sentral faktor for korttidsplassenes funksjon og for at økt bruk av tidsbegrenset opphold i institusjon skal fungere hensiktsmessig. For å kontrollere for betydningen av hjemmetjenester inkluderes «dekningsgrad av hjemmetjenester for sert ved å dele «antall mottakere av pleie- og omsorgstjenester med omfattende bistandsbehov» på "antall mottaker av hjemmetjenester totalt».

Når det gjelder omfanget av de hjemmebaserte tjenestene, utgjør «andel hjemmetjenestemottakere som mottar minst to hjemmetjenester» et sentralt mål. For å kontrollere for omfanget av de hjemmebaserte tjenestene, inkluderes «andel hjemmetjenestemottakere som mottar minst to hjemmetjenester (x6)» i analysen. Denne variabelen er operasjonalisert ved å dele «antall hjemmetjenestemottakere som mottar minst to hjemmetjenester» på "antall mottaker av hjemmetjenester totalt».

For å kontrollere for demografiske og sosioøkonomiske forhold, inkluderes «andel innbyggere 80 år og eldre (x7)», "alders- og kjønnsstandardisert dødelighet $(\mathrm{x} 8)$ ", "andel aleneboende (x9)» og «andel med kort/lang høyskole-/universitetsutdanning (x10)». For utenom «alders- og kjønnsstandardisert dødelighet» er de øvrige variablene operasjo- nalisert ved å dele det absolutte antallet på «antall innbyggere totalt» for hver enkelte kommune i 2010. «Alders- og kjønnsstandardisert dødelighet» er den gjennomsnittlige dødelighetsraten for årene 2002-2006, fordelt på kommune, beregnet av Statistisk sentralbyrå.

Kommunenes evne til å motta utskrivningsklare pasienter vil kunne avhenge av kompetansen blant de ansatte i den kommunale pleie- og omsorgssektoren. Mange av de eldre pasientene som skrives ut fra somatiske sykehus vil trolig kreve høy medisinsk og pleiefaglig kompetanse, noe som stiller krav til kompetansen blant de ansatte i pleie- og omsorgssektoren. For å kontrollere for betydningen av de ansattes kompetanse-nivå inkluderes «andel avtalte årsverk i pleie og omsorg med fagutdanning (x11)» $i$ analysen. Variabelen er operasjonalisert ved å dele «antall avtalte årsverk i pleie og omsorg med fagutdanning» på «antall avtalte årsverk i brukerrettet tjeneste i pleie og omsorg totalt».

Kommunenes evne til å ta imot eldre somatiske pasienter for rehabilitering og etterbehandling, og ikke minst avverge reinnleggelser, vil kunne avhenge av hvorvidt og i hvilken utstrekning det er satt av ressurser til aktivisering innenfor pleie- og omsorgssektoren i den enkelte kommune. For å undersøke betydningen av aktivisering inkluderes «andel avtalte årsverk med aktivisering i pleie og omsorg (x12)» som en kontrollvariabel i analysen. Variabelen er operasjonalisert ved å dele «antall avtalte årsverk til aktivisering i pleie og omsorg» på «antall avtalte årsverk i brukerrettet tjeneste i pleie og omsorg totalt».

Sammenhengen mellom kommunestørrelse og inntektsnivå 
gjør at det spesielt er de minste kommunene som har mest ressurser per innbygger, og dermed har muligheten til å tilby innbyggerne et godt utbygd tilbud innen pleie- og omsorgssektoren (16). Den bivariate korrelasjonen mellom kommunestørrelse (målt som antall innbyggere) og frie inntekter per innbygger var i 2010 på -0,822 (Pearsons r). «Frie inntekter per innbygger (i 1000 kroner) (x13)» i 2010 inkluderes $\mathrm{i}$ analysen for å kunne kontrollere både betydningen av kommunestørrelse, samt kommunenes økonomisk handlingsrom.

Når de kommunale inntektene stort sett er gitt i form av frie inntekter, blir hovedoppgaven til de lokale beslutningstakerne å prioritere innenfor de gitte rammene. Pleie og omsorg utgjør en stor og kostnadskrevende del av den kommunale virksomheten. For å kontrollere for betydningen av lokale prioriteringer, tas derfor «andel nettoutgifter til pleie og omsorg (x14)» med i analysen. Variabelen er operasjonalisert ved å dele «nettoutgifter til pleie og omsorg» på «nettoutgifter totalt» for hver kommune i 2010.

\section{RESULTATER}

Resultatene i tabell 1 viser at «andel liggedøgn tidsbegrenset opphold» virker negativt inn på «antall liggedøgn i somatiske sykehus per pasient 80 år og eldre», når det kontrolleres for de øvrige uavhengige variablene i modell 2. Analysen viser dermed at somatiske pasienter 80 år og eldre har lavere liggetid i sykehus i kommuner med utstrakt bruk av korttidsplasser. Artikkelens hypotese får dermed støtte. Som nevnt er gjennomsnittlig andelen korttidsplasser i norske kommuner 20,47 prosent. Men variasjonen er betydelig, og i kommunen med høyest andel korttidsplas- ser er hele 94,65 prosent av sykehjemsplassene brukt som korttidsplasser. For å undersøke hvilken betydning "andel liggedøgn tidsbegrenset opphold" har for «antall liggedøgn i somatiske sykehus per pasient 80 år og eldre», har vi estimert antall liggedøgn i somatiske sykehus etter kommunens bruk av korttidsplasser (se tabell 1). I beregningen av det estimerte «antall liggedøgn i somatiske sykehus per 80 år og eldre» (Y) holdes de øvrige uavhengige variablene konstante ved å multiplisere gjennomsnittsverdien $\left({ }^{-} \mathrm{X}\right)$ for hver variabel med regresjonskoeffisienten for de respektive variablene. Gitt disse forutsetningene, vil kommunen med den høyeste bruken av korttidsplasser (94,65 prosent) i 2010 ha et estimert «antall liggedøgn i somatiske sykehus per 80 år og eldre» (Y) på 3,51 i 2011. Til sammenlikning vil en kommune med gjennomsnittlig bruk av for eldre pasienter på somatiske sykehus. Både offentlige dokumenter og forskningsbidrag på feltet har pekt på korttidsplasser som et viktig tiltak for å redusere liggetiden i somatiske sykehus. Et tiltak i spennet mellom ordinære hjemmetjenester og ordinære langtidsplasser på institusjon. Imidlertid har det verken fra myndighetshold eller blant forskningsbidragene på feltet vært initiert eller gjennomført representative statistiske analyser for samtlige norske kommuner. Noe som gjør det vanskelig å gi et generelt bilde av betydningen av korttidsplasser for pasientstrømmen og dermed liggetiden i somatiske sykehus. Styrken ved denne studien er at den nettopp tilfører forskningen på feltet en slik analyse. Dermed gir den også et mer generelt bilde av betydningen av korttidsplasser i kommunale institusjoner for antall liggedøgn i somatiske sykehus per pasient

\section{Samhandlingsreformen har endret arbeidsdelingen mellom statlige helse- foretak og kommunale tjenester.}

korttidsplasser (20,47 prosent) i 2010 ha et estimert «antall liggedøgn i somatiske sykehus per 80 år og eldre» (Y) på 4,31 i 2011. Forskjellen i det estimerte «antall liggedøgn i somatiske sykehus per 80 år og eldre» er dermed 0,8 døgn mellom kommunen med den mest utstrakte bruken og kommuner med en gjennomsnittlig bruk av korttidsplasser i 2010.

\section{DISKUSJON}

Innføringen av samhandlingsreformen har aktualisert spørsmålet om hvilken funksjon korttidsplassene har i de kommunale pleie- og omsorgstjenestene for å sikre en god pasientstrøm og dermed bidra til redusert liggetid
80 år og eldre i norske sykehus. Artikkelen søkte å teste følgende hypotese: Somatiske pasienter 80 år og eldre har lavere liggetid i sykehus i kommuner med utstrakt bruk av korttidsplasser. Resultatene fra analysen ga støtte til denne hypotesen og resultatene gir dermed også støtte til de funn og argumenter som er blitt presentert på forskningsfeltet basert på data fra enkeltkommuner $(10,11,15)$.

Den fullstendige analysemodellen forklarer kun 6,7 prosent av variasjonen $\mathrm{i}$ «antall liggedøgn i somatiske sykehus per pasienter 80 år og eldre i 2011» (jf. R2). Det er dermed 93,3 prosent av variasjonen $\mathrm{i}$ «antall liggedøgn 
Tabell 1: Antall liggedøgn i somatiske sykehus per pasienter 80 år og eldre i 2011 (x)

\begin{tabular}{|c|c|c|}
\hline & $\begin{array}{l}\text { Modell } 1 \text { B } \\
\text { (BETA) }\end{array}$ & $\begin{array}{l}\text { Modell } 2 \text { B } \\
\text { (BETA) }\end{array}$ \\
\hline Konstant & $4,236 * * *$ & $7,600^{* * *}$ \\
\hline Andel liggedøgn tidsbegrenset opphold (2010) (x2) & $\begin{array}{l}-0,0012 \\
(-0,0151)\end{array}$ & $\begin{array}{l}-0,106^{* *} \\
(-0,1227)\end{array}$ \\
\hline Dekningsgrad av institusjonsplasser for innbyggere 80 år og eldre (2010) (x3) & & $\begin{array}{l}-0,0154 \\
(-0,0728)\end{array}$ \\
\hline Dekningsgrad av hjemmetjenester for innbyggere 80 år og eldre (2010) (x4) & & $\begin{array}{l}-0,0033 \\
(-0,0185)\end{array}$ \\
\hline Andel hjemmetjenestemottaker som mottar minst to hjemmetjenester (2010) (x5) & & $\begin{array}{l}0,0047 \\
(0,0317)\end{array}$ \\
\hline Andel brukere med omfattende bistandsbehov (2010) (x6) & & $\begin{array}{l}0,0121 \\
(0,0639)\end{array}$ \\
\hline Andel innbyggere 80 år og eldre (2010) (x7) & & $\begin{array}{l}-0,0988 \\
(-0,1307)\end{array}$ \\
\hline Alders- og kjønnsstandardisert dødelighet. Gjennomsnitt 2002-2006 per 100000 innbygger (x8) & & $\begin{array}{l}-0,0024^{* * *} \\
(-0,2151)\end{array}$ \\
\hline Andel aleneboende (2010) (x9) & & $\begin{array}{l}0,0499 * \\
(0,1218)\end{array}$ \\
\hline Andel med kort/lang høyskole-/universitetsutdanning (2010) (x10) & & $\begin{array}{l}0,0034 \\
(0,0048)\end{array}$ \\
\hline Andel årsverk i pleie og omsorg med fagutdanning (2009) (x11) & & $\begin{array}{l}-0,0149 * * \\
(-0,1101)\end{array}$ \\
\hline Andel årsverk med aktivisering i pleie og omsorg (2009) (x12) & & $\begin{array}{l}-0,0091^{*} \\
(-0,1077)\end{array}$ \\
\hline Frie inntekter per innbygger (i 1000 kroner) (2010) (x13) & & $\begin{array}{l}-0,0007 \\
(-0,0060)\end{array}$ \\
\hline Andel nettoutgifter til pleie og omsorg (2010) (x14) & & $\begin{array}{l}-0,0089 \\
(-0,0378)\end{array}$ \\
\hline N & 425 & 408 \\
\hline Modellens forklaringskraft av variasjonen i avhengig variabel/Justert $\mathrm{R}^{2}$ & 0,000 & 0,067 \\
\hline \multicolumn{3}{|c|}{$\begin{array}{l}\text { Estimert «antall liggedøgn i somatiske sykehus per } 80 \text { år og eldre» ved høyest bruk av korttidsplasser: } \\
7.600+(-0.0106 * 94,65)+(-0.0105 * 16,11)+(-0.0033 * 36,31)+(0.0047 * 32,62)+(0.0121 * 23,7)+(-0.0988 * 5,53)+\left(-0.0024^{*} 742,69\right)+ \\
(0.0499 * 15,47)+(0.0034 * 3,11)+(-0.015 * 70,82)+(-0.0091 * 29,75)+(-0.0007 * 42,83)+(-0.0089 * 35,83)=3,51\end{array}$} \\
\hline \multicolumn{3}{|c|}{$\begin{array}{l}\text { Estimert «antall liggedøgn i somatiske sykehus per } 80 \text { år og eldre» ved gjennomsnittlig bruk av korttidsplasser: } \\
7.600+(-0.0106 * 20,47)+(-0.0105 * 16,11)+(-0.0033 * 36,31)+(0.0047 * 32,62)+(0.0121 * 23,7)+(-0.0988 * 5,53)+\left(-0.0024^{*} 742,69\right)+ \\
(0.0499 * 15,47)+(0.0034 * 3,11)+(-0.015 * 70,82)+(-0.0091 * 29,75)+(-0.0007 * 42,83)+(-0.0089 * 35,83)=4,31\end{array}$} \\
\hline
\end{tabular}

i somatiske sykehus per pasienter 80 år og eldre i 2011» som forklares av forhold som ikke er tatt med i modellen. Nå må det sies at det er få studier av samfunnsmessige forhold som oppnår en svært høy forklart varians, fordi fenomenene man ønsker å forklare typisk varierer langs så mange dimensjoner. Det er også tilfelle her. Samtidig har dette datasettet, som alle andre, sine begrensninger. To av de viktigste er etter vår vurdering at vi ikke har tilstrekkelige opplysninger om døgntilbud utenfor institusjon, typisk omsorgsboliger, og at vi ikke har tilgang til opplysninger om diagnoser. Vi har dermed vært begrenset til å se på betydningen av korttidsplasser versus langtidsplasser i institusjoner, og mangler opplysninger om omfang og bruk av omsorgsboliger med varierende bemanning. Mangelen på opplysninger om diagnoser innebærer at vi ikke fanger opp forskjeller mellom kommuner som følger av at helsesituasjonen kan variere blant 
de eldste, noe som vil virke inn på antallet liggedøgn. Det vil være en utfordring for framtidig forskning å utvikle mer fingraderte analyser som tar høyde for variasjon i samlet tjenestetilbud og helsetilstand i kommunene. Slike analyser kan også med fordel inkludere variabler som regionale forskjeller og reiseavstand til nærmeste somatiske sykehus. Som en ekstra kontroll kjørte vi en analyse uten «andel døgn korttidsplasser» i modellen, for å se hvor mye variabelen isolert sett bidrar til den forklarte variansen (tabellen er ikke vist). Denne analysen viste at bruken av korttidsplass kun forklarer 1,1 prosent av variasjonen $i$ «antall liggedøgn $i$ somatiske sykehus per pasienter 80 år og eldre i 2011", som er relativt lavt. Dette kan ha sammenheng med at vi kun har hatt anledning til å se på den totale bruken eller kapasiteten av korttidsplasser. Et mer nyansert mål ville kunne vært å benytte «antall utskrivninger fra korttidsplasser» (12). Det er ikke nødvendigvis slik at den totale bruken eller kapasiteten av korttidsplasser er av størst betydning for liggetiden i somatiske sykehus dersom noen få pasienter opptar korttidsplassene over lengre tid. Høy sirkulasjon vil derimot kunne gi mange tilgang på et korttidsplasstilbud når de skrives ut fra sykehus. Selv om korttidsplassene forklarer relativt lite, har andelen korttidsplasser en betydning for antallet liggedøgn på somatiske sykehus for de eldste som er statistisk signifikant, også når vi kontrollerer for en rekke andre relevante variabler. Jo høyere andel korttidsplasser, jo færre liggedøgn. Dette er i tråd med hypotesen vi la til grunn, og styrker også funn fra andre norske studier som er gjennomført med andre typer data. Sammenhengen er svak, men den går i forventet retning.

\section{KONKLUSJON}

Resultatene i denne artikkelen er basert på data fra 2010 og 2011, det vil si før Samhandlingsreformen ble satt i virksomhet. Det virker imidlertid rimelig å anta at betydningen av korttidsplasser vil tilta under denne reformen. Det kommunale medfinansieringsansvaret, de sentrale myndighetenes vektlegging av korttidsplasser og forskningen på feltet peker i retning av at kommuner som satser på korttidsplasser bør fortsette med det. Analysene i denne artikkelen, kombinert med tidligere norske studier, støtter en anbefaling til kommuner med knapp kapasitet av korttidsplasser om at de bør øke denne. Dette for å møte de utfordringer reformen medfører og de muligheter kommunale korttidsplasser gir for god pasientstrøm og dermed lavere liggetid i somatiske sykehus. Imidlertid er det fortsatt mye vi ikke vet om forholdet mellom korttidsplasser på institusjon og andre trekk ved det kommunale omsorgstilbudet når det gjelder å forklare variasjonen $\mathrm{i}$ «antall liggedøgn i somatiske sykehus per pasienter 80 år og eldre i 2011». Kommende forskning på feltet vil med fordel kunne utprøve andre mål på tilgjengelighet og bruk av korttidsplasser enn det som har vært mulig i den foreliggende analysen. Videre vil analyser av data etter gjennomføringen av Samhandlingsreformen kunne belyse hvorvidt betydningen av korttidsplasser vil tilta. Dette er et felt i rask utvikling, og det vil være behov for studier som angriper problematikken fra ulike vinkler og med ulike data.

En stor takk til Ivar Brevik og Leif Moland for meget gode innspill underveis $i$ arbeidet med artikkelen.

\section{REFERANSER}

1. Folkehelseinstituttet. Andelen personer over 65 år i befolkningen. 2013 [Nedlastet ned 2013 14.06]; tilgjengelig på URL: http://www.fhi.no/ artikler $/$ ?id=70828.

2. St.meld. 47. Samhandlingsreformen (2008-2009). Rett behandling - på rett sted - til rett tid. Helse- og omsorgsdepartementet. Oslo.

3. St.meld. nr. 9 (1974-75). Sykehusutbygging $\mathrm{m} \vee \mathrm{i}$ et regionalisert helsevesen. Sosial- og helsedepartementet. Oslo.

4. Gautun H, Grøden AS, Hermansen $\AA$. Prioriteringsutfordringer mellom yngre og eldre brukere: Forskningsstiftelsen Fafo; 2013.

5. Gautun H, Kjerstad E, Kristiansen F. Mellom to senger?: eldre sykehuspasienter og det kommunale pleie-og omsorgstilbudet. 2001.

6. NOU1992:1. Trygghet - Verdighet Omsorg. Sosial- og helsedepartementet. Oslo.

7. St.meld. 25. Mestring, muligheter og mening (2005-2006). Framtidas omsorgsutfordringer. Helse- og omsorgsdepartementet. Oslo.

8. Kaurin M, Lossius MC. Statistikk om bruken av korttids-og rehabiliteringsplasser i kommunene. Overordnede trekk og samhandling Pleie- og omsorgsstatistikken gir ny innsikt. Oslo: Helsedirektoratet 2012.

9. Torvestad S, Mikkelsen AL, Ferkingstad L, Richter T, Bjelke B, Kristoffersen $E$, et al. Rapport om: "Pasientforløp for eldre skrøpelige pasienter" Et pilotprosjekt om samhandling mellom Haugesund kommune, Haugesund Sykehus og Høgskolen Stord/Haugesund. 2011.

10. Otterstad HK, Tønseth H. Hvordan unngå sykehjemskø. Aldring og livsløp. 2007;4:20-4.

11. Otterstad HK, Birkestrand T, Sorteberg K. Fordeling og bruk av korttidsplasser i sykehjem. Sykepleien. 2004;92:48-51.

12. Otterstad HK, Tønseth H. Sykehjemsdriften i Norge. Hva betyr dekningsgraden for sirkulasjon, pleietyngde og dødelighet? Aldring og livsløp. 2007(1).

13. Otterstad HK, Tønseth H. Store forskjeller i sykehjemsdrift og tilgjengelighet. Aldring og livsløp 2007(1).

14. Hjelmbrekke S, Løyland K, Møller G, Vardheim I. Kostnader og kvalitet i pleie-og omsorgssektoren: Telemarksforsking; 2011.

15. Otterstad HK. Klare for sykehjem, blir på sykehus. Sykepleien. 2009;13:56. 16. Rattsø J, Sørensen RJ. Kommunen som serviceprodusent/tjenesteyter: Hva forteller norsk kommuneforskning om kommunesektorens effektivitet?'. Kommunalt selvstyre i velferdsstaten Oslo: Tano. 1997. 